\section{CERIMÔNIA DE DEFINIÇÃO: 0 PERCURSO ENTRE A PRIMEIRA E A SEGUNDA ESCUTA NO PROCESSO DE FORMAÇÃO DO TERAPEUTA}

\author{
DEFINITION CEREMONY: THE PATHWAY BETWEEN THE FIRST AND SECOND \\ LISTENING IN THE THERAPIST TRAINING PROCESS
}

RESUMO: 0 artigo apresenta uma experiência de teoria em ação na formação da autora no Instituto Familiae, de São Paulo, entre 2010 e 2014, por meio de um caso atendido no curso em dezesseis sessões. Trata do impacto provocado pela escuta da primeira sessão da terapia familiar, designada como "primeira escuta", em contraste com as reflexões surgidas, decorridos três anos, o que está sendo nomeado como "segunda escuta". Desde uma perspectiva sócioconstrucionista e como integrante de uma equipe reflexiva, a autora faz algumas reflexões sobre conceitos como linguagem constitutiva da realidade, empoderamento, posição de não saber e dialogismo, entremeando a discussão desses conceitos, das mudanças que eles propõem e das transformações que promoveram na escuta e no ser/estar em relações da autora com o relato de fragmentos de algumas sessões. 0 título Cerimônia de Definição é inspirado na abordagem narrativa de Michael White e consolida a apropriação dos recursos adquiridos no percurso da formação e também no processo de escrita deste relato. 0 artigo foi escrito com base em registros escritos e de áudio das sessões selecionados, mantendo a cronologia original. Os nomes dos participantes foram alterados para preservar 0 anonimato.

PALAVRAS-CHAVE: Construcionismo Social; Posição de não saber; Terapia Narrativa; Dialogismo; Processos Reflexivos.
ABSTRACT: The article presents an experience of theory in action in its author's formation at Instituto Familiae of São Paulo between 2010 and 2014, through a case attended at the Institute in sixteen sessions. It addresses the impact of listening to the first session of family therapy, referred to as "first listening", in contrast to the reflections that have emerged after three years, which is being called "second listening." From a socio-constructive perspective and as a member of a reflecting team, the author makes some reflections about concepts such as constitution of not-knowing and dialogism, amidst the discussion of these concepts, the changes they propose and the transformations they promote listening and in the author's relations with the report of fragments of some sessions. The title Ceremony of Definition is inspired by Michael White's Narrative Approach and consolidates the appropriation of the resources acquired in the formation course as well as in the writing process of this account. The article was written based on written and audio records of the selected sessions, maintaining the original chronology. Participant names have been changed in order to preserve their anonymity

KEYWORDS: Social Constructionism; Not-Knowing Position; Narrative Therapy; Dialogism; Reflecting Processes. tive language of reality, empowerment, posi-

Tornamo-nos sujeitos à medida que a linguagem e suas significações passam a modular a maneira como nos relacionamos com o passado e o futuro, o ambiente físico e cultural, os semelhantes e nossa própria materialidade corporal

ANA LUISA COUTINHO Instituto Noos, São Paulo, Brasil.

Recebido em: 10/09/2017 Aprovado em: 07/02/2018 
A linguagem não só "faz pensamentos" como também "faz realidades".

Thomas Ibañez Gracia

\section{INTRODUÇÃO}

Esse artigo é fruto do meu trabalho de conclusão da formação em Terapia de Casal e Família no Instituto Familiae, de São Paulo, que encerrou as atividades em 2014. Tendo como pano de fundo a transformação da minha escuta como terapeuta durante o processo de formação em terapia familiar ${ }^{1}$, proponho uma reflexão sobre a teoria em ação, num contexto de atendimento que me gerou um grande impacto pela sua complexidade e proporcionou refletir sobre a teoria que embasava o curso, assim como as crenças que me constituíam naquele momento, conformando meu ser/estar em relações.

Escolhido esse caso para fazer o trabalho, fui rever, três anos depois, as gravações e me surpreendi pela maneira diferente como escutava tanto as seções de atendimento quanto as conversas com as supervisoras e colegas de equipe. Esta surpresa me levou a revisitar o meu percurso na formação e fazer um relato deste processo, que culminou no que chamei de segunda escuta. No registro desta segunda escuta, pude identificar os recursos que foram adquiridos durante minha caminhada no curso, que resultaram em uma escuta diferente e numa nova forma de ser e estar nas relações. As conversas que aconteciam durante as supervisões e as conversas em equipe me levaram a interrogar sobre o papel da linguagem na criação de sentido, sobre o diálogo, sobre o papel do terapeuta e sua postura colaborativa à luz do Construcionismo Social. Para operacionalizar todo este processo, res- gatei os registros dos atendimentos a uma família feitos no começo do curso, do qual participei, junto com duas colegas, como integrante da Equipe Reflexiva. Estar na equipe reflexiva, prática desenvolvida por Tom Andersen (2002), possibilitou ouvir tanto a voz dos clientes como as minhas vozes internas num processo de tornar-me observadora do meu próprio observar. Da mesma maneira, conceitos derivados da abordagem da Terapia Narrativa de Michael White, tais como história alternativa e testemunha externa, bem como a Cerimônia de Definição, ritual que utilizo como título do trabalho, conferiram mais consistência a habilidades e recursos que foram adquiridos ao longo do atendimento e do meu próprio processo na formação.

Além de descrever o percurso da terapeuta em treinamento e as mudanças percebidas ao longo do processo, proponho fazer neste artigo uma reflexão sobre a mudança de paradigma - de uma perspectiva moderna da noção de conhecimento e da postura do terapeuta especialista para a perspectiva construcionista social, que inclui o papel da linguagem e do diálogo na construção conjunta de significados elementos que também contribuíram para uma escuta diferente. É esta a razão em optar por primeiro apresentar o contexto do atendimento, as minhas primeiras inquietações, para depois descrever mais detalhadamente os conceitos e posições teóricas a que fui apresentada ao longo da formação. Revendo a sequência dos atendimentos, faço, em seguida, uma discussão desses conceitos à luz das mudanças que fui percebendo em mim e na minha escuta reflexiva, num enlaçamento entre a experiência e a teoria.

$\mathrm{O}$ atendimento era feito por uma dupla de terapeutas no campo e três terapeutas na equipe reflexiva. Após o 
atendimento, reuníamo-nos para conversar sobre o que havia tocado cada uma e que contribuições essas conversas trariam às terapeutas de campo. Os clientes eram uma tia e quatro sobrinhos, filhos de seu irmão e órfãos de mãe, que ela ajudava a criar. Aquela senhora se sentia desautorizada no lugar de tia/mãe, principalmente pelo sobrinho mais velho que havia convivido por mais tempo com a mãe biológica. A família havia sido encaminhada pela escola de uma das crianças em razão de seu mau comportamento. Como já mencionado anteriormente, o Instituto Familiae encerrou as atividades em 2014 e, no momento em que os atendimentos aconteceram, não foi solicitado o termo de consentimento livre esclarecido. Desta forma, visando atender as normas éticas e ao mesmo tempo compartilhar uma experiência que, para mim, foi tão enriquecedora, troquei os nomes dos sobrinhos dessa senhora, a quem chamarei de "Tia", e modifiquei algumas situações, intervindo também na transcrição dos diálogos de forma a não ser possível identificá-los. Os atendimentos ocorreram ao longo de um ano, nos meses de março, abril, maio, junho, agosto, setembro, outubro e dezembro de 2011, totalizando dezesseis encontros quinzenais. As sessões foram gravadas, com o consentimento dos clientes, como parte do processo de formação do Instituto e transcritas posteriormente para a elaboração do trabalho de conclusão.

\section{CONSTRUÇÃO DA NARRATIVA - UMA PRIMEIRA ESCUTA}

Os atendimentos haviam sido solicitados para uma senhora, a "Tia", e seus quatro sobrinhos, respectivamente, Roberto, 16 anos; Sandro, 14 anos; Luís, 13 anos e Rodrigo, 9 anos.
Apesar de a procura ser para terapia de família, a Tia chega sozinha para a primeira sessão. Indagada sobre o porquê da decisão de comparecer sozinha, ela começa a contar sua história:

Tia - Hoje eu resolvi vir só porque, bem, a convivência com a mãe deles já era uma péssima convivência. Meu irmão é usuário de drogas, ela também, eu acho, não usava diretamente, isso a gente nem sabia... Depois ela mesma disse que também já era soropositiva e eu não sei se ela teve medo de contar. Porque, eu fico pensando, como antes do meu irmão ela já tinha sido casada e isso chegou até nós e não foi ela que disse, que o primeiro homem dela era um assaltante de banco, segundo os comentários. Depois ficamos sabendo que ele foi morto na cadeia e não sei como meu irmão voltou a encontrá-la. Sei que eles começaram a morar juntos... No começo, quando estava tudo flores era ela e meu irmão lá no canto deles. Acho que a partir do momento que as coisas começaram a ficar feias pro lado dela, difíceis, segundo o meu irmão, ele dizia que sabia das más amizades dela, que ele não queria ter contato, mas ela insistia. Ele vivia com a pessoa errada, ela já tinha bastante conhecimento e queria que meu irmão fizesse amizade com aquelas pessoas e foi aí que ele caiu na vida também. Eu não sei se ela era soropositiva desde a época desse primeiro casamento, e a gente sem saber de nada... Depois que ele começou a usar [drogas] foi quando começaram as brigas.

T - Você não sabia nem dela nem do seu irmão... ou do seu irmão você sabia?

Tia - Não, a gente não sabia de nenhum dos dois. Eu só vim 
saber quando ela teve a última criança... e ela tinha um tumor na cabeça.

$\mathrm{T}$ - Me explica uma coisa... eles tiveram quantos filhos juntos?

Tia - Tiveram as quatro crianças... Ela não estava conseguindo cuidar, por causa do tumor né, aí quando eu cheguei na primeira consulta os médicos começaram com tantas perguntas... tantas perguntas e eu sem saber responder até que eles perguntaram: "Nossa, o que está acontecendo? A senhora não sabia?". Eu contei que ela tinha pedido pra eu dar um remedinho [para o caçula], pensei que era um xaropinho, mas era o... até esqueci... O médico perguntou: "A senhora deu direitinho?" Eu dei, acho que, se não me engano, uma noite passou desapercebida, mas eu dei... Daí os médicos falaram: "Então precisamos conversar com a senhora. Vamos ali na salinha". Fui eu e ele, meu irmão... Não sei não se ele não sabia, um primo estava internado e nós fomos chamados para doar sangue... daí ele constatou que tinha hepatite e não podia doar. Não sei, só sei que ele ficou assim descontrolado e eu sem saber. Para mim o mundo acabou... Parece que abriu um buraco assim e eu entrei. Ela já tinha falecido fazia uns 6 meses e aí eu fui pensando, eu não estava preparada para isso... Eu já observava que ela só falava em paulada... Com o primeiro [filho], sempre naquela grosseria... Esse mais velho é tão revoltado da vida, mas revoltado mesmo e ela era daquelas mães erradas mesmo, ela fazia coisa errada e também só andava com quem não prestava, né? Roubava, diz que ela saía com esse mais velho, levava o menino junto, isso é um absurdo, ele é tão revoltado esse mais velho, tão revoltado...

\section{$\mathrm{T}-E ́$ o Roberto?}

Tia - Sim, o Roberto... nossa, ele ia pra escola ele pulava muro, saía com os colegas da vida errada. Daí a escola me ligava eu ia, conversava, aí eu falava, falava... Ele é que nem o pai, caladão, não responde... agora esse mais velho se envolveu com uma mulher que... Olha só a situação, é outra que já se envolveu com três homens, diz que é tudo bandido. Desse último que ela separou parece que ele tá preso... Sabe, o pessoal que conhece eles está sempre dando um toque pra gente e não tem como controlar... Eles abrem o portão com grampo... Meu irmão é usuário, mas ele trabalha e quando chega sexta-feira ele vai pra porta do bar e só volta quase na hora de ir trabalhar. Na segunda-feira ele tá ruim, ruim... Não sei como ele consegue... Usa o coquetel... Outro dia ele ficou tão ruim que achou que dessa vez ele ia... Bem, situação crítica, os meninos veem ele desse jeito na porta do bar... Meu Deus, o Roberto, acho que pelo fato da mãe dele sair para roubar junto com ele, da mãe dele só querer coisa de marca, querer tudo de bom, ele é do mesmo jeito. O Sandro já não tem essa mania de pegar as coisas dos outros, nem o Luís... O menor é que, coisa de criança, às vezes eu penso como que pode as coisas serem assim... O Roberto que sempre teve mania de pegar as coisas dos outros... não sei se pelo fato dele sair sempre com a mãe... O Luís vai muito pela cabeça dos outros. O Rodrigo é mais sossegado, mais amoroso. Às vezes ele vem dar um abraço. $O$ ano passado ele deu tanto trabalho na escola que 
o diretor queria até que eu tirasse ele da escola... Acho que é pelo fato do trabalho que ele deu, só que eu não vou tirar... Porque aonde já se viu uma professora chamar o aluno de lixo? A professora chamou ele de lixo... A outra fez um boletim de ocorrência... A criança, na cabeça dela acho, ela achou que ele ia fazer alguma coisa com ela porque ela mesmo que falou assim. Isso é o cúmulo do absurdo um seu humano chamar o outro de lixo... As queixas que tenho dele é que ele fala muito... Não para de falar, fala alto, grita, grita, sempre foi essa a queixa.

\section{TRANSFORMANDO PARA UMA NOVA ESCUTA}

O impacto deste primeiro atendimento foi disparador de um processo de transformação; algumas reflexões emergiram logo após o primeiro atendimento, para mim uma avalanche de problemas tão complexos, num contexto de tanta carência e falta de recursos, que me tirou o fôlego. Os problemas eram despejados pela Tia, com o que eu diria certa urgência; às vezes ficava difícil entender exatamente o que ela queria dizer. Parecia-me que ela ficava constrangida ao contar todas aquelas histórias falando de roubo, drogas etc.; falava rápido, comendo palavras e deixando coisas subentendidas, como no caso de o Roberto gostar de "pegar" as coisas dos outros e no caso do caçula ao dizer que "isso" era coisa de criança.

No decorrer da sessão, fui ficando cada vez mais abalada com o que ouvia, não teria imaginado nada semelhante àquele relato. Ao mesmo tempo em que me sentia sensibilizada pelo sofrimento da Tia e com a falta de perspectiva dos meninos, também ficava assustada com as histórias envolvendo criminalidade e drogas. Como poderíamos ajudá-los? Aquela história me conectava com os déficits; fiquei focada tanto na falta de assistência por parte do Estado, como na precária situação financeira da família. Como aqueles jovens teriam, naquele contexto, sem recursos financeiros e sem uma boa educação, um futuro diferente do de seus pais?

Para mim, vinda de outro contexto socioeconômico, certos requisitos básicos são necessários para que as pessoas possam enfrentar situações de carência. Naquele momento, tanto eu quanto a Tia estávamos imbuídas de uma ideia de efeito causal e determinista, em que o meio ambiente, a condição social e todas as faltas decorrentes dela implicavam uma vida sem muitas oportunidades e escolhas. Nessas circunstâncias, via o atendimento da família como uma tarefa impossível. Pensando no terapeuta como responsável por ter que encontrar o melhor caminho para eles, ficava paralisada frente a tantas dificuldades.

Para aumentar minha inquietação e desconforto, comentamos que teríamos que avisá-los de que as sessões seriam gravadas. Então, o que era um desconforto se transformou em medo, muito medo. Como iríamos gravar sessões com pessoas que estavam envolvidas com assaltantes, usuários e traficantes de drogas? Ao gravarmos as sessões, a que risco estaríamos nos expondo? Compartilhei com as colegas o meu medo e a preocupação com a questão de nossa segurança. Como conciliar o ter que fazer as gravações como parte do acordo para atendimento, visto que estávamos numa clínica-escola, com o fato de que, por questões éticas, eles teriam de ser in- 
formados e consentirem? Considerava o contexto no qual a família estava inserida, com traficantes e assaltantes, de muita violência e de um código "moral" que tinha regras próprias as quais me eram desconhecidas e de que só ouvira falar através da mídia.

Pensava que, se porventura nosso papel como terapeutas fosse de alguma maneira uma ameaça para eles (traficantes e criminosos com quem a família estava envolvida), nossa integridade física poderia estar em risco. O meu medo era uma voz muito presente em todas as nossas conversas. No entanto, essa questão não era um problema para minhas colegas. Sentia-me frustrada por não conseguir me fazer entender. Naquele momento, eu acreditava que se fazer entender era uma questão de bons argumentos, mas as razões que para mim eram claras e faziam tanto sentido não tinham o mesmo significado para elas.

A decisão de trazer meu medo para a roda de conversa não foi fácil, porém, ele estava presente, conformando o meu estar nas relações. Assim, percebendo a necessidade de trabalhar o impacto que esse medo causava em mim e o efeito que tinha na relação com a equipe, trouxemos esta conversa para as interlocuções em sala de aula. Foi o ponto de partida para o processo reflexivo intenso que vivi nesse atendimento.

\section{ENLAÇANDO A TEORIA E A PRÁTICA}

Sentido de agência, uma experiência de sermos capazes de agir competentemente, por nós mesmos.

Harlene Anderson e Harold

Goolishian
As ideias sócioconstrucionistas inspiraram e nortearam a prática de atendimentos no Instituto em que realizei a minha formação de terapeuta familiar. Uma das premissas centrais desta epistemologia é a de que teoria e prática não se separam e, além disso, a prática é o fundamento e o que guia as teorizações. Transitando entre teoria e prática, tecemos uma trama de conceitos, recursos, conhecimentos, num processo de aprendizagem mútuo e interativo entre famílias atendidas e profissionais que participam do atendimento. Discutirei a seguir alguns conceitos e teorias que foram sendo construídas e apropriadas ao longo do processo da formação e as mudanças que esses conceitos refletiram na escuta terapêutica do caso que está sendo relatado e no meu próprio posicionamento como terapeuta desde então.

\section{Construcionismo Social}

Abordagem teórica que se situa na pós-modernidade, surgida no contexto das ciências humanas, propondo um novo entendimento para a concepção e produção de conhecimento. É uma perspectiva caracterizada pela ênfase dada à linguagem e à interação entre as pessoas na compreensão dos processos de construção de sentido. Para os construcionistas, é a partir das nossas práticas discursivas inseridas num contexto social e histórico que produzimos as descrições de realidade (Gergen \& Gergen, 2010). Seguindo a argumentação de Gergen, não se trata de imagens do mundo, mas sim de ações práticas no mundo. Assim, são as relações e não os indivíduos que produzem os significados e, portanto, podemos entender o significado como uma ação coordenada. A perspectiva construcionista nos convida a uma 
multiplicidade de ideias e discursos em detrimento de uma verdade universal e a uma postura de curiosidade e respeito para com outras tradições. Sugere que cada tradição possui seus valores, e a verdade seria, então, uma forma consensual de falar que confirmaria as tradições de determinada comunidade e se daria nas relações. "Todas as construções do verdadeiro estão ancoradas nas formas de vida, e todas as formas de vida se caracterizam por valores" (Gergen \& Gergen, 2010, p. 30). Adotar as premissas do Construcionismo Social traz implicações para a prática, ou seja, nos faz questionar sobre a universalidade do entendimento dos fenômenos, levando-nos a entendê-los como construções sociais. A ideia principal é que tudo que nomeamos como real o é porque assim o consideramos, e esta definição se restringe a um contexto e uma tradição cultural, ou seja, a construção de sentido se dá a partir de nossas atividades colaborativas. Como dizem Gergen e Gergen (2010), tanto as palavras que usamos como os nomes que atribuímos uns aos outros são usados para efetuar relações.

Assim, na perspectiva sócioconstrucionista, mais importante do que explicar a natureza do mundo e conhecer a origem das coisas é compreender como as pessoas coordenam suas ações em torno dos sentidos de mundo que constroem em seus relacionamentos, e quais possibilidades de vida e interação esses sentidos podem impedir ou favorecer. Desta maneira, o terapeuta passa a ter seu foco no processo e não em objetivos pré-determinados, tais como a busca da causa e da verdade sobre os problemas. Isto traz implicações tanto para a prática da terapia quanto para o lugar ou posicionamento do terapeuta, que, no processo de terapia como constru- ção social, estará implicado na coconstrução de novos significados e novas possibilidades na vida do cliente. Em outras palavras, o papel do terapeuta é ressignificado como o de um parceiro conversacional.

\section{Equipe Reflexiva}

Recurso muito utilizado em cursos de treinamento e formação de terapeutas de família, é um modelo, proposto pelo psiquiatra norueguês Tom Andersen, em que algumas das pessoas presentes no atendimento - equipe reflexiva - observam e depois fazem reflexões em voz alta a partir de sua escuta. Neste modelo, a equipe terapêutica é formada em geral por um ou dois terapeutas trabalhando em dupla que conduzem o atendimento à família no campo, constituindo, na denominação de Andersen (2002), o sistema entrevistador; e dois ou mais terapeutas e outros profissionais que assistem em silêncio à conversa do sistema entrevistador e depois compartilham suas ideias e reflexões. Essas contribuições podem ser feitas através de metáforas ou perguntas que não foram feitas pela equipe de campo e têm a finalidade de ampliar as narrativas e fomentar o aparecimento de novas possibilidades para se resolver a questão que os clientes levam à terapia. No nosso caso, a equipe reflexiva era composta de três terapeutas e uma dupla de terapeutas no campo.

Além das conversas com a equipe e com a classe, que me foram muito úteis, creio também que estar na equipe reflexiva me proporcionou tempo para que eu ouvisse tanto o diálogo externo que acontecia na terapia como o diálogo interno que acontecia comigo durante esse processo. Como diz Tom Andersen (2002), a conversa interna 
ocorre quando a pessoa para de falar com o outro e faz o que considera uma pausa. Esta pausa, no entanto, não é uma pausa, ela apenas "retrocede" ou "desloca-se" para outro lugar, "encontra-se com outra pessoa” (p. 157). O diálogo interno é como um processo circular que ocorre entre o sentir, conhecer e agir que tem duas finalidades: uma, estar a serviço da preservação da integridade da pessoa e outra, como uma base para expandir o sentir, conhecer e agir. Sugere pensar que recebemos ideias das falas externas que não tínhamos antes, e nossas falas internas com nós mesmos selecionam quais das novas ideias desejamos incluir em nossos hábitos de falar.

\section{A linguagem como constitutiva da realidade}

Dentre todas as novidades com as quais fui entrando em contato durante a formação, a primeira e mais impactante foi o conceito da linguagem como constitutiva de realidade. Esse conceito foi muito revolucionário, levou-me a pensar em várias questões que estavam de certa forma subordinadas a ele, e refletiam minha maneira de ser e me relacionar. No momento do atendimento aqui descrito, o vocabulário que eu tinha para descrever aquela família e seu contexto era de déficit, impotência, medo, perigo; ele conformava a maneira como eu via a Tia e os meninos, e como me relacionava com eles e também com minhas colegas. Conversar sobre o meu medo naquele cenário soava como preconceito para minhas colegas, embora eu mesma não me sentisse preconceituosa. Como explicar o que acontecia ali? Se eu falava/pensava assim, precisava investigar de onde vinham essas ideias que me faziam agir de maneira dife- rente do que gostaria. Algumas pistas surgiram quando fui apresentada à virada paradigmática, conhecida como giro linguístico. Movimento surgido nas décadas de 70 e 80 do século XX, o assim chamado giro linguístico surgiu para dar nova ênfase ao papel da linguagem e às implicações desta na natureza do conhecimento e na própria noção da constituição do sujeito (Gracia, 2004). Para entender a mudança que o giro linguístico representou na concepção do mundo e na interpretação das ciências humanas e sociais, é preciso refletir sobre nossa concepção de linguagem até então. Até aquele momento, o foco da atenção estava no mundo das ideias, e a linguagem seria representante de uma realidade existente a ser exteriorizada. Imperava, além disto, a hegemonia da filosofia da consciência, em que era preciso conhecer o mundo interior, o mundo das ideias, para conhecer o mundo exterior, ou seja, a realidade. A partir deste movimento de giro linguístico, o foco foi deslocado para a construção da realidade na relação e para a construção conjunta de significados na linguagem. Essa ênfase promoveu estudos que ampliaram o entendimento tanto da função da linguagem como dos seus mecanismos. Como argumenta o filósofo Ludwig Wittgenstein (1996), a linguagem funciona em seus usos, não cabendo, portanto, indagar sobre os significados das palavras, mas sobre suas funções práticas (p. 14). Ou seja, o jogo dos significados é, basicamente, um jogo dentro da linguagem, compreendido dentro dos padrões de ação a que chamamos contexto (Grandesso, 2006, p. 201). Além disto, o papel da linguagem passa a ir além da função descritivo-representacional e influi tanto na nossa forma de pensar como na maneira como nos relacionamos com as pessoas (Gracia, 2004). 
Assim, durante o processo conversacional que se dava em classe e assistindo aos atendimentos, questionei as crenças e inquietações que me constituíam naquele momento vindo a ressignificá-las, o que promoveu mudanças em meu vocabulário e na minha escuta.

\section{Uma posição de não saber}

De acordo com Anderson e Goolishian (1998), não saber não é ter julgamento sem base ou sem experiência; refere-se mais a um conjunto de suposições de significado que o terapeuta traz à entrevista clínica e examina junto com o cliente. Adotar essa postura traz implicações para o papel do terapeuta e para o próprio processo terapêutico, influindo de forma determinante na maneira de estar e escutar o cliente. Nessa posição o terapeuta se torna um aprendiz da vida do cliente, que, por sua vez, assume o papel de professor: "o terapeuta é o especialista em se encaixar e participar com o cliente em um processo dialógico de narração de histórias em primeira pessoa" (Anderson, 2011, p. 81). Em outras palavras, movido pela curiosidade e orientado por um posicionamento de não saber, a tarefa principal do terapeuta se torna a de encontrar perguntas que favoreçam a ampliação do relato que o cliente traz, perguntas que emergem da narrativa conjunta que acontece naquele momento. Ainda na argumentação de Anderson (p. 122), o não saber permite possibilidades que o saber não permite.

No momento da primeira escuta, meus saberes sobre a vida daquela família em seu contexto preenchiam as lacunas do que ela ainda não havia dito com muitas histórias paralelas complementadas pelas minhas cren- ças, levando-me a sentir medo e falta de esperança. $\mathrm{O}$ medo me levava para outros lugares e para outras histórias que não eram propriamente as dela só conseguia ver carência e obstáculos, além do perigo. $\mathrm{O}$ efeito determinista que a história da Tia tinha na vida dela e da família fazia ressonância em mim e era reforçado pela maneira como eu a ouvia. No decurso do atendimento, no entanto, aquelas histórias que eram generalizadas e generalizantes foram ganhando particularidades; elas agora tinham um nome, uma fisionomia. Despertavam meu interesse as mudanças que eu percebia na maneira diferente de eles falarem dos problemas, pensando em caminhos e possibilidades que antes não existiam.

\section{Dialogismo}

Quando iniciei a formação, ainda orientada pelo paradigma moderno, meu entendimento de diálogo era de que, nele, eu representava minha intenção, meus sentimentos e transmitia uma posição ou informação, ou seja, comunicava meu pensamento, minhas ideias. De acordo com este entendimento, a linguagem é informativa de realidade. Com essa postura monológica não há abertura para o outro e não se tem oportunidade de estar em conversação (Anderson, 2011). Seria como participar de uma competição arraigada em defender opiniões e posições, onde nada muda e nenhum significado novo acontece, como falar para si mesmo. Em contrapartida, nas terapias pós-modernas e de orientação Construcionista Social, o conceito de diálogo é o processo pelo qual se produz a criação conjunta de conhecimento e significados (Gergen \& Gergen, 2010). Ou seja, são processos conversacionais que possibilitam a 
produção de conhecimento sobre nós mesmos e sobre o mundo em que vivemos (Shotter, citado por Guanaes, 2006). Nessa perspectiva, conversar é mais que colocar ideias em palavras ou refletir a realidade; é, de fato, construir sentidos, práticas sociais, ou, nos termos de Wittgenstein (1996), formas de vida. Por isto, a unidade de investigação do discurso não pode ser a palavra isolada, mas sim o enunciado, isto é, unidades mínimas de significação que se constroem, se encadeiam e adquirem sentido no diálogo entre interlocutores (Guanaes, 2006, p. 31). Mikhail Bakhtin (Souza, 2012), filósofo e crítico literário russo, formulou uma teoria sobre esses encadeamentos dialógicos, a que deu o nome de Teoria da Enunciação. De acordo com esta teorização, a verdade não se encontra no interior de uma única pessoa, mas está no processo de interação dialógica entre pessoas que a procuram coletivamente. Assim, o enunciado não pode ser entendido como representativo, mas sim como responsivo; é a resposta do outro que dá ao enunciado seu sentido. Consequentemente, o sentido será sempre uma realização momentânea, resultado da interação dialógica de um ou mais interlocutores num determinado tempo e contexto. Como a compreensão, ainda segundo Bakhtin (Souza, 2012), é um processo ativo e criativo em que aquele que compreende participa do diálogo, continuando a criação de seu interlocutor, multiplicando a riqueza do que já foi dito, uma nova maneira de conversar se configurava para mim, onde o processo de criar sentido, compreensão e entendimento se dá na e através da linguagem e nas relações. A qualidade das interlocuções que ocorreram na classe durante o período que durou o atendimento da família promovia reflexão e tempo para uma conversa in- terna a fim de que novos significados pudessem emergir. Foram conversas colaborativas, nas quais as diferenças eram acolhidas e questionadas de forma reflexiva, sem julgamento, em que havia um misto de compreensão e de cocriação de novos significados e de uma nova identidade.

\section{Terapia Narrativa - Testemunhas externas e Cerimônia de Definição}

Originalmente associada aos nomes de Michael White e David Epston (1993), a Terapia Narrativa e outras práticas a ela associadas vêm sendo desenvolvidas há mais de vinte anos em diferentes contextos. Esta abordagem terapêutica pode ser considerada uma virada paradigmática que organizou uma prática discursiva e derivou em ações, tendo como metáforas norteadoras do trabalho clínico os conceitos de "narrativa" e "construção social” (Guanaes, 2006). As pessoas costumam chegar à terapia com histórias saturadas de problemas e costumam fazer descrições de si como sendo o problema. A Terapia Narrativa, no entanto, vê o problema como independente, externo à pessoa; o terapeuta narrativo busca, por meio de perguntas, diferenciar o problema da pessoa, num processo chamado de externalização, em que tanto o problema quanto seus efeitos e influências na vida da pessoa são nomeados (White, 2012; White \& Epston, 1993). O afastamento entre a pessoa e o problema proporciona um agenciamento de reautoria de uma nova história (Morgan, 2007). Portanto, por meio de perguntas, as crenças e ideias que sustentam o problema podem ser examinadas e ressignificadas, dando lugar a novas narrativas. Essas ideias encontram ressonância na proposta que Jerome Bru- 
ner faz para a narrativa literária: "uma grande história contada (...) sobre tramas eloquentes que (...) devem ser apresentadas com subjetividade suficiente para permitir que sejam reescritas pelo leitor, reescritas de maneira a permitir que a imaginação do leitor brinque" (Bruner, citado por White, 2012, p. 89). Uma terapia eficaz, neste sentido, diz respeito a envolver pessoas na reautoria de tramas convincentes de suas vidas, que incitem a curiosidade sobre a possibilidade humana e de modo que invoquem o jogo da imaginação. O propósito do terapeuta é facilitar o resgate de histórias de habilidades e competências que possibilitem um novo enredo, não mais centrado no déficit ou no problema que elas têm em suas vidas, mas sim nos recursos para enfrentá-los. São as chamadas histórias alternativas. No caso que apresento neste trabalho, as narrativas eram saturadas de negatividade e dificuldades e os meninos "eram" o problema. Aos poucos, à medida que a conversa na terapia favorecia que outras histórias fossem contadas, os problemas foram se "descolando" das crianças e um sentimento de esperança se instalando na vida deles.

Outro recurso que White propõe para dar reconhecimento às novas histórias que emergem é a chamada Cerimônia de Definição, uma prática/ritual inspirada no trabalho da antropóloga norte-americana Barbara Myerhoff que tem um papel importante em ajudar as pessoas no resgate ou redefinição de suas identidades. White (2012) sugere escolher pessoas que tenham um significado e uma ligação com a história do cliente, mas que, em geral, não estavam presentes nos atendimentos; são as testemunhas externas. Esse ritual oferece uma oportunidade para as pessoas contarem ou representarem sua história perante uma audiência específica (testemunhas externas), que irão depois recontar o que ouviram e apontar o que mais chamou atenção: as imagens que os relatos evocaram, as ressonâncias com o relato e sentimentos sobre como sua vida foi tocada pela narrativa. Em sintonia com essas ideias, resolvi nomear o meu processo, no curso e nos atendimentos, de Cerimônia de Definição como forma de dar visibilidade e sustentação às mudanças que vivi durante meu percurso. Num processo de mão dupla, minha proposta de trabalho entusiasmou minha orientadora e, ao perceber seu entusiasmo como um reconhecimento do caminho que trilhei, pude perceber as conquistas que tinha alcançado. Assim, nomeei como minhas testemunhas externas, neste caso, minha orientadora e minha colega de formação que fazia dupla comigo na Equipe Reflexiva pelas transformações que elas enxergavam em mim.

\section{A SEGUNDA ESCUTA}

Ao ouvir, passados três anos, a gravação do primeiro atendimento, me surpreendi pela maneira diferente como eu estava ouvindo as conversas. O que teria favorecido essa nova escuta? De que novo lugar eu estava escutando? Que transformações já haviam ocorrido nas minhas crenças para que minha escuta tivesse mudado durante o ano que durou aquele atendimento e durante o processo da minha formação no Familiae? Essa escuta, que designei segunda escuta, me instigou a pensar nos recursos que eu havia adquirido e nas crenças que haviam mudado. Levou-me a refletir sobre o percurso do meu processo de formação e na mudança dos conceitos que eu tinha anteriormente, como o papel da linguagem, o agenciamen- 
to pessoal, o não saber, a priori, o diálogo. Assim, revisitei meu percurso e descrevi o processo que se deu nas transformações de muitas das crenças que conformavam meu estar no mundo. Vivi a teoria em ação, o que reforça algo que foi comunicado no primeiro dia de aula: "este é um curso que tem a duração de quatro anos porque não é um curso de informação, mas sim de formação, e esta se dá entre o saber e o fazer". Pude vivenciar, especialmente no período que durou o atendimento, o papel transformador da conversa dialógica que, em contraste com "com a conversa educada ou com confrontação adversária, os dois participantes sofrem mudança" (Anderson, 2011).

As transformações dos conceitos acima referidos tiveram reflexos no meu entendimento, tanto do papel do terapeuta como do papel da terapia. Saí de uma posição dar algo para alguém, para o de construir um significado conjunto, em "que os sentidos do cliente e do terapeuta se afetam mutuamente, e passam a ser um subproduto desta mutualidade" (Anderson \& Goolishian, 1998, p. 42). Num processo dialógico, terapeuta e cliente geram um sentido que emerge no momento da conversão terapêutica num processo contínuo de mudança. Vivi essa experiência na prática das conversas em que participei com a equipe, as quais me levavam a refletir sobre minhas crenças, identificar os enlaces que fazia com o que ouvia da Tia e que remetiam a mim. Por outro lado, algumas crenças da Tia eram também questionadas, tal como o papel tão influente da mãe das crianças, que já havia morrido. Neste processo dialógico e reflexivo, entendi que as conversas que tínhamos não eram para descobrir causas ou justificativas, mas para ampliar uma narrativa restritiva e aprisionante que possibilitasse criar novos significados e novas perspectivas de vida. Sair do lugar de terapeuta especialista em saber da vida do outro para o outro tirou um peso que me imobilizava e promoveu uma curiosidade natural de querer saber do outro a partir do outro. A Tia e eu tínhamos um peso que nos imobilizava, que era a força determinista que as histórias dela traziam. Percebia a mudança que ocorria na minha escuta à medida que ela ia se libertando desta determinação e maior agenciamento aparecia. Trabalhar minhas afetações e crenças e as emoções que elas geravam em mim me possibilitaram ficar mais conectada com o outro. Os problemas não haviam diminuído, continuavam lá; a condição social e financeira, a qualidade do ensino, as drogas, roubos, mas a perspectiva pela qual eu estava ouvindo havia mudado. Nas palavras de Anderson (2011), "quando acreditamos que conhecemos o ponto da história, por assim dizer, cortamos e fechamos acesso ao não dito" (p. 99).

Dentre os dezesseis atendimentos que foram feitos ao longo do ano, escolhi para apresentar neste trabalho os que mais me mobilizaram pela mudança que constatei. Em contraste com a primeira narrativa, em que o déficit e a falta de esperança reinavam determinando seus destinos, pude perceber as mudanças que ocorriam na família à medida que surgiam novas narrativas e novos significados para os problemas que traziam, um verdadeiro contraenredo.

\section{A construção de cidades}

O sobrinho mais novo era muito envergonhado, acho que não ouvimos a voz dele durante todos os atendimentos. Porém, ele brincava o tempo 
todo no meio da sala, com blocos de madeira, fazendo várias construções. Em uma das sessões, ele trouxe uma carta para as terapeutas, dizendo o quanto ele gostava de ir aos encontros e que elas o ajudavam a construir cidades. Foi muito tocante esta declaração, que eu chamo de amor. Que coisas diferentes aconteciam ali, que não aconteciam na casa deles? Que maneira de se relacionar diferente acontecia ali? Em outro momento - após feriados e um período maior sem haver atendimento - a Tia comentou que ele sentiu muitas saudades das "meninas" (como ele chamava as terapeutas).

\section{0 dia das mães}

No quinto encontro já percebíamos uma grande mudança na maneira deles se relacionarem e contarem suas histórias. Chegaram para o atendimento a Tia e os quatro meninos. Ela comentou que as coisas estavam melhores e que percebia que os meninos estavam se esforçando. Ela estava visivelmente alegre e contou que, pela primeira vez, os meninos deram parabéns para ela. Eles ficaram tristes por não conseguirem comprar um presente, ao que ela respondeu:

Tia - Presente não me interessa, o que me interessa é que eu tenha que ir menos na escola... Que não vá mais, de jeito nenhum, ter que chegar lá e passar toda aquela vergonha...

$\mathrm{T}$ - O que aconteceu este ano que vocês resolveram dar parabéns para a Tia?

Os meninos não souberam contar, mas disseram que antes só davam parabéns para a avó. Percebi que, através das conversas que aconteciam na tera- pia, as crianças puderam validar o lugar que esta tia ocupava na vida deles, e ela também pôde assumir esta posição de uma "cuidadora" que estava no lugar de mãe.

\section{0 sobrinho mais velho}

Outro momento que me tocou muito foi um dos últimos encontros que tivemos. O sobrinho mais velho, Roberto, tinha faltado a vários encontros quando havia decidido começar a vender drogas. As terapeutas, no entanto, continuavam perguntando por ele e reforçando o convite para que ele voltasse. Ele foi aos últimos atendimentos, parece que estava em liberdade assistida, tendo que comparecer à psicóloga do Fórum, da qual ele não gostava. Numa das idas, contou chorando do medo que tinha de a Tia entregá-los para a família da mãe. Revelava uma grande preocupação quando entendia que a Tia, cansada, às vezes ameaçava mandá-los embora. $\mathrm{E}$ ele pedia que ela nunca fizesse isso, não por ele, mas pelos irmãos. Nesse momento, ao sentir-se reconhecida, a Tia pôde assumir esse papel de tia/mãe que ela é para os meninos e dizer que nunca os mandaria embora.

\section{A construção de novas possibilidades}

O último atendimento foi uma sessão emocionante, na qual fizemos uma finalização conjunta, terapeutas e equipe reflexiva na sala, cada uma ofertando uma contribuição para eles levarem como lembrança dos encontros - um documento no formato de uma carta, que contava sobre o processo que eles viveram ali, um desenho, livros infantis e blocos de madeira para que eles continuassem juntos a construção de novas possibilidades. 
De acordo com o formato de atendimento no Instituto, seria proposta uma sessão de seguimento alguns meses após o encerramento da terapia. No entanto, não conseguimos fazê-la, pois a Tia estava trabalhando e não pôde ir. Permaneceu a nossa crença de que as mudanças que aconteceram ali puderam trazer efeitos para os problemas que eles queriam ver resolvidos.

\section{CONSIDERAÇÕES FINAIS}

Este é o relato da minha experiência no caminhar da formação em terapia de família em que um novo paradigma se apresentou como uma nova filosofia de vida e, talvez, possa servir de inspiração para outras pessoas que se disponham a fazer esta trajetória.

O desafio de escrever o trabalho de conclusão do curso de formação me levou a uma viagem no tempo, em que revisitei a teoria que foi apresentada no curso enquanto revia as gravações do atendimento, numa dança da teoria em ação. Esse processo propiciou refletir nas crenças que me constituíam ao começar o curso e que me conformavam como aluna/terapeuta/ colega e com as mudanças que foram acontecendo ao longo do curso e que me transformaram na terapeuta que eu buscava ser. Uma terapeuta que fosse uma parceira conversacional, que tivesse um interesse e curiosidade genuína, e que pudesse aprender do outro, pelo outro.

Aprendi que o aprendizado é um processo que nunca se esgota, e que podemos usar nosso conhecimento como uma caixa de ferramentas atentos para o que mais se adéque em ajudar nossos clientes na direção da mudança que eles querem alcançar em suas vidas.
Questões como o livre-arbítrio e a capacidade de fazer escolhas sempre me intrigaram. Se por um lado sentimos a força do contexto, da herança genética e cultural dando um caráter determinista à vida, por outro a possibilidade de fazer escolhas reforça a ideia de livre-arbítrio. No entanto, fazer escolhas não é uma atividade fácil e termina por reforçar a impressão do caráter causal na vida das pessoas. Qual seria então o fator que possibilitaria a autonomia e gestão da própria vida em detrimento da força determinista? Essa curiosidade sempre me deixou reflexiva e observadora dos processos que ocorrem nas interações e na busca por essa capacidade de fazer escolhas que gerem mudanças. Pensava, no entanto, que essa capacidade de agenciamento, muitas vezes referida como empoderamento, era uma habilidade que necessitava ser aprendida e desenvolvida. Além disso, acreditava que esse aprendizado seria dado por alguém com um saber especializado, no caso, o terapeuta. Assim, tinha vontade de conhecer mais sobre essa aptidão de empoderar alguém e também interesse em me capacitar para poder ajudar as pessoas a aprenderem a ser donas de suas vidas. Quando comecei a participar do atendimento aqui relatado, ainda estava imbuída da ideia do terapeuta especialista que saberia ensinar o cliente a como resolver seus problemas. Nesse caso, a tarefa de empoderar a família me parecia bastante árdua e difícil em vista de tanta carência e tantas dificuldades. A responsabilidade de ter que saber como solucionar os problemas relatados gerava um peso muito grande e um sentimento de impotência; não sabia por onde começar. Pensar dessa maneira tinha reflexos na minha escuta e na minha postura frente aos clientes e às minhas colegas. Contudo, ao entrar 
em contato com o novo paradigma proposto pelo construcionismo social e suas premissas, esta crença foi questionada e ressignificada e deu lugar a novas perguntas. Se nos constituímos na linguagem e nela criamos significados conjuntamente, o que precisava acontecer para as pessoas serem agentes de novas escolhas?

Aprendemos com White e Epston (1993) que as pessoas vivem e compreendem seu viver por meio de narrativas construídas socialmente, que conferem sentido e organização à sua experiência. A narrativa daquela família fazia pensar que todos estavam presos a um passado que conformava suas vidas, restringindo as alternativas a um modelo de pensamento determinista: as coisas são como são. No entanto, durante as conversas do processo terapêutico foram acontecendo transformações que seriam o desdobramento das possibilidades ainda não ditas e de narrativas ainda não relatadas. Dessa maneira, o processo conversacional terapêutico pode acelerar a evolução de novas realidades pessoais e de uma nova capacidade de ação, que emergem do desenvolvimento de novas narrativas. Com efeito, as conversas geraram uma nova maneira de ver a realidade e promoveram um movimento em direção a novas alternativas para as questões que a Tia dos meninos que estávamos atendendo queria ver resolvidas.

Fui percebendo que o agenciamento pessoal se dava no diálogo que ali acontecia e que possibilitava que as pessoas reconhecessem suas competências e habilidades, construindo uma nova narrativa para suas vidas. Assim, falavam de si com mais energia e esperança. Como dizem Anderson e Goolishian (1998), essa nova capacidade de ação narrativa é o que é vivenciado como libertação por aqueles que identificam um processo terapêutico como bem-sucedido. Ao constatar essa transformação em processo pude aprender que minha responsabilidade como terapeuta não era a de dar poder para alguém, mas sim criar um espaço conversacional em que novas formas de falar sobre o problema gerassem novos caminhos e novas formas de ação.

A experiência de viver as transformações da minha escuta a partir da prática e perceber a incorporação de um novo paradigma no meu ser/estar em relações teve um efeito muito marcante para mim. Aprender um novo paradigma é como aprender uma segunda língua, você não pensa e não sonha nela; no começo não tem um vocabulário vasto o suficiente para se expressar com facilidade. Todavia, durante o caminho que percorri, me apropriei de mais recursos e estes me deram mais fluência. Fui ficando mais à vontade nesse lugar, mais familiarizada com este paradigma. Sinto-me cativada e envolvida por esse convite de ser/estar de uma maneira diferente. Não mais verdadeira ou mais certa, mas, com certeza, mais útil e frutífera. Nesse processo pude dar corpo e consistência para uma nova narrativa em que reconheci minhas habilidades e os recursos que favoreceram para que eu pudesse realizar o projeto de me tornar uma terapeuta familiar.

\section{REFERÊNCIAS}

Andersen, T. (2002). Processos reflexivos ( $1^{\text {a }}$ ed.), Rio de Janeiro: Instituto Noos.

Anderson, H. (2011). Conversação, linguagem e possibilidades. São Paulo: Editora Roca.

Anderson, H. \& Goolishian, H. (1998). O cliente é o especialista: uma abor- 
dagem para terapia a partir de uma posição de não saber. In S. McNamee \& K. Gergen (Orgs.), Terapia como Construção Social (pp. 34-49). Porto Alegre: Artes Médicas.

Gergen, K. J. \& Gergen, M. (2010). Construcionismo Social: um convite ao diálogo. Rio de Janeiro: Instituto Noos.

Grandesso, M. A. (2006). Sobre a reconstrução do significado. São Paulo: Casa do Psicólogo.

Guanaes, C. (2006). A construção da mudança em Terapia de Grupo. São Paulo: Vetor.

Gracia, T. I. (2004). O giro linguístico. In L. Iñiguez (Ed.), Manual de Análise do Discurso em Ciências Sociais (pp. 19-49). Petrópolis, RJ: Vozes.

Morgan, A. (2007). O que é Terapia Narrativa? Porto Alegre: Centro de Estudos e Práticas Narrativas.

Souza, S. J. (2012). Infância e Linguagem: Bakhtin, Vygotsky e Benjamin. São Paulo: Papirus.

Wittgenstein, L. (1996). Investigações filosóficas (Coleção Os Pensadores). São Paulo: Nova Cultura.

White, M. (2012). Mapas da Prática Narrativa. Porto Alegre: Pacartes.

White, M. \& Epston, D. (1993). Medios narrativos para fines terapéuticos. Barcelona: Paidós.

\section{ANA LUISA COUTINHO}

Terapeuta de família e casal - Mediadora voluntária no projeto de mediação familiar para idosos em situação de risco da Promotoria de Justiça Cível do Foro Regional de Santo Amaro, integrante da equipe clínica do Instituto Noos, São Paulo, SP, Brasil.

E-mail: analuisacoutinho27@gmail.com 